\title{
Ontogenesis from embryo to juvenile and salinity tolerance of Japanese devil stinger Inimicus japonicus during early life stage
}

\author{
Youji Wang ${ }^{\dagger}$, Lisha Li ${ }^{\dagger}$, Guoqiang Cui and Weiqun $\mathrm{Lu}^{*}$
}

\begin{abstract}
Embryonic development and morphological characteristics of Japanese devil stinger Inimicus japonicus during early life stage were investigated. Larvae were hatched out $50 \mathrm{~h}$ after fertilization at temperature $21^{\circ} \mathrm{C}$. Total length of the newly hatched larva was $4.03 \mathrm{~mm}$, the mouth of the larva opened at 3 days after hatching (DAH), and the yolk sac of the larva disappeared at $5 \mathrm{DAH}$. After hatching, the pectoral fin first developed, then the tail fin, dorsal fin, anal fin and pelvic fin continuously developed, and all fins formed completely at $15 \mathrm{DAH}$. The metamorphosis was complete at $25 \mathrm{DAH}$, and the body color and habit of the metamorphosed individuals were different from the larvae. At $30 \mathrm{DAH}$, the morphology and habit of the juveniles were the same to adults. In order to determine the suitable salinity for larviculture of I. japonicus, salinity tolerance at different early developmental stages was compared in terms of the survival activity index (SAI) and mean survival time (MST). The results indicated that salinity tolerance varied with development stages. The optimum salinity range for newly hatched larvae was 1025\%. Larvae showed low tolerance to low salinity (5\%) before the mouth opened, and the suitable salinities for the larvae with open mouth, yolk-sac larvae, post yolk-sac larvae were 10-15\%o. The flexion larvae showed a wider salinity tolerance with range of 5-20\%. After metamorphosis, the juveniles showed a preferable adaptability of salinities of $15-20 \%$. The SAI and MST of individuals at various stages under different salinity conditions were positively correlated.
\end{abstract}

Keywords: Inimicus japonicus; Early development; Morphological characteristics; Larvae; Juvenile; Salinity tolerance

\section{Introduction}

The devil stinger Inimicus japonicus, a valuable demersal marine scorpaenid fish, is widely distributed along the coastal areas of eastern Asia with depth range 10-200m, where salinity fluctuates frequently due to rainfall in summer. During its reproductive season, the larvae may suffer environmental changes severely such as salinity fluctuation, but little is known about their salinity tolerance during their early stage. The devil stinger is one of the species for which artificial seed production and cultivation have been developed along the coastal areas of China and Japan to increase the harvest yield since the early 2000s, and it has been considered to be a new

\footnotetext{
*Correspondence: wqlv@shou.edu.cn

'Equal contributors

College of Fisheries and Life Science, Shanghai Ocean University, Key Laboratory of Exploration and Utilization of Aquatic Genetic Resources, Ministry of Education, 999 Huchenghuan Road, Shanghai 201306, China
}

commercially important species to be introduced into the aquaculture industry (Takushima et al. 2003; Liu and Quan 2005; Kadomura et al. 2006; Chen et al. 2009; Kim et al. 2012). However, the wild population of the devil stinger has declined rapidly because of overfishing and habitat destruction, it is urgent to conduct relevant studies on resource conservation and artificial breeding. In China and Japan, some hatcheries have tried to establish seed production, but success has not yet been attained because of sudden mass mortality during the larviculture in recent years (Kim et al. 2012). Rearing conditions, egg quality, and diseases are suspected as causes for this (Kadomura et al. 2006). Information regarding its early life history and larviculture, which can provide useful information for developing conservation and management plans, has not been well reported. There is an urgent need for researchers to learn about the larval biology of 
this species, and to provide some useful information to culture this species.

There are some studies on reproductive biology and osteological development of I. japonicus (Imamura and Yabe 1997; Takushima et al. 2003; Nozaki et al. 2003). The reproductive cycle of devil stinger has been investigated, and its spawning season is from May to August, with peaks from May to June (Nozaki et al. 2003). Although attempts have been made to establish seed production and entire aquaculture process for this species (Takushima et al. 2003; Liu and Quan 2005), the technique has not been fully developed, and studies on larval ecology are still lacking, especially the salinity tolerance during early life stage has not been elucidated. Sudden mass mortality during the larval rearing stage due to unknown causes is a serious problem. Inappropriate rearing or feeding conditions, defects in egg quality, and infectious diseases are suspected as causes of sudden mass mortality (Kim et al. 2012). It is therefore necessary to accumulate fundamental information on the larval biology of this species in order to establish the technique for artificial seed production.

Study on early life history characters of fish makes a fundamental key for enabling a closer approach to their biology and taxonomy (Meijide and Guerrero 2000; Celik et al. 2012). Morphological characteristics are very important as they provide information of life history of fish and critical reference to hatchery production (Martinez and Bolker 2003). In addition, studies on embryonic and larval development of any fish species can be useful in directing the husbandry efforts of fish breeder to the specific state and requirements of each development stage (Celik et al. 2012). Chen et al. (2009) investigated the feeding rhythm and lethal time during starvation of the devil stinger I. japonicus. However, detailed study about the embryonic and larval development of scorpionfish is scarce. In addition, information is lacking concerning ontogeny of Japanese devil stinger I. japonicus from egg to juvenile.

Salinity plays an important role in embryonic development, yolk sac absorption, larval and juvenile growth Boeuf and Payan (2001). Embryonic and larval stages are two sensitive periods during fish life history, changes in environmental conditions may cause negative effects on larval development, and inappropriate culture condition may result in mass mortality of larval fish. Thus it is useful to study the salinity tolerance of fish during early life stages and choose the suitable salinity for larviculture (Boeuf and Payan 2001). Some reports of the effects of salinity on growth and survival of larval fish, such as Caranx mate (Santerre 1976), brown-spotted grouper Epinephelus tauvina (Akatsu et al. 1983), gilthead sea bream Sparus aurata (Tandler et al. 1995) and Brazilian flounder Paralichthys orbignyanus (Sampaio et al. 2007) larvae, indicated an increase in survival and/or growth at intermediate salinities ( $>15$ ppt but $<30 \mathrm{ppt}$ ). Others found improved growth or survival of larvae at higher salinities (>34 ppt), such as milkfish Chanos chanos (Swanson 1996) and southern flounder Paralichthys lethostigma (Henne and Watanabe 2003; Moustakas et al. 2004). Moreover, no significant differences in growth were observed among different salinities in cobia Rachycentron canadum larvae (Faulk and Holt 2006). Thus, results vary among species and across developmental stages. The devil stinger $I$. japonicus is known to exhibit surface death from hatching to the first feeding stage during the process of larval production (Ruttanapornvareesakul et al. 2007), whether salinity can affect the survival in this period is still unclear. In the present study, the embryonic and larval development of laboratory-reared I. japonicus from egg to juvenile were described in detail, major morphological changes during larval development were investigated. In addition, salinity tolerance of devil stinger during early life stage was investigated. Survival activity index (SAI) and mean survival time (MST) of larvae, which are expressed as functions of tolerance to starvation of larvae (Furuita et al. 2000; Matsuo et al. 2006), have been used as effective indexes for assessment of salinity tolerance in larval I. japonicus.

\section{Materials and methods}

\section{Broodstock maintenance}

Thirty males (body weight $600 \mathrm{~g}$ ) and thirty females (body weight $300 \mathrm{~g}$ ) of I. japonicus were purchased from Ningde Fish market (Ningde, Fujian province), and were used as broodstock in the experiment. They were fed with commercial seawater fish feeds (Guangdong Yuehai Feed Group, Guangdong, China; Protein: 39\%, Fat: 5\%, Fibre: 3\%, Ash: $15 \%$, Moisture: $10 \%$ ), three times a day. During broodstock culture, water temperature, $\mathrm{pH}$, salinity and $\mathrm{DO}$ were monitored daily at $21 \pm 0.5{ }^{\circ} \mathrm{C}, 8.0-8.1,28-30 \%$ and $7.0-8.0$ $\mathrm{mg} \mathrm{l}^{-1}$ respectively. The photoperiod was maintained at 12L/12D by fluorescent lighting (lights on: 07:00-19:00 hours). Broodstocks were kept in two 500-l tanks. Female spawning was induced by intraperitoneally injecting luteinizing hormone-releasing hormone analogue (LRHA3) and human chorionic gonadotrophin (HCG). The doses of these two hormones for female were $5 \mu \mathrm{g} / \mathrm{kg}$ and $800 \mathrm{IU} /$ $\mathrm{kg}$, and males were injected with half doses of them. Spawning was observed $50 \mathrm{~h}$ after injection.

\section{Observations and measurements of embryos and larvae}

Fertilized eggs were collected and incubated in 500-1 tanks filled with clean seawater $(30 \%)$. The incubation tank was held at temperature $21.0^{\circ} \mathrm{C}$ and dissolved oxygen $7.0-8.0 \mathrm{mg} \mathrm{l}^{-1}$. Some of them were transferred into a beaker $(500 \mathrm{ml})$ for embryonic development observations. Eggs were observed from spawning to hatching under an 
electron microscope (OPTON EM10C, Carl Zelss Company, Germany, No.5166, voltage is 60KV) and photographed using a colour video camera (Panasonic ZS10, Japan). Embryonic development stages were identified according to Jones et al. (1978) and Kimmel et al. (1995).

Newly hatched larvae were reared in incubation tanks and the density was maintained at $2 \times 10^{4}$ ind. $\mathrm{m}^{-3}$ from 1 day after hatching (DAH) to $5 \mathrm{DAH}$. From $6 \mathrm{DAH}$ to $11 \mathrm{DAH}$, the water was changed $30 \%$ everyday and the density was reduced to $1 \times 10^{4}$ ind. $\mathrm{m}^{-3}$. From $12 \mathrm{DAH}$ to $25 \mathrm{DAH}$, the water was changed $50 \%$ daily, and the culture density was $5 \times 10^{3}$ ind. $\mathrm{m}^{-3}$. After $26 \mathrm{DAH}$, the fish were transferred to tanks which were circulated by flowing seawater, and the culture density was 1000 ind. $\mathrm{m}^{-3}$. The larvae were fed with rotifers and chlorella from $3 \mathrm{DAH}$ to 20 DAH; and Artemia nauplii from $12 \mathrm{DAH}$ to $30 \mathrm{DAH}$. From $20 \mathrm{DAH}$, artificial diets were supplied to the fish until the end of the experiment. Larvae were randomly sampled $(\mathrm{n}=10)$ daily from hatch to $50 \mathrm{DAH}$. These specimens were observed under a dissecting microscope (JAPAN ASONE, IS/Mill-E, China) equipped with TSView software. On the other hand, samples were used for observations on general morphology and for the following morphometric measurements (Figure 1): body depth (BD), eye diameter (ED), head length (HL), pectoral fin length (PL), body length (BL) and total length (TL). Larval developmental stages were identified according to Kendall et al. (1984) and differentiated into six periods, I: newly hatched larva (1 DAH), II: yolk-sac larva (2 DAH), III: mouth-open larva (3 DAH), IV: post yolk-sac larva (5 DAH), V: flexion larva (15 $\mathrm{DAH})$ and VI: juvenile (25 DAH).

\section{Salinity tolerance test at different developmental stages} Salinity tolerance test was conducted following the method of Matsuo et al. (2006). Selected developmental stages included: newly hatched larva (1 DAH), yolk-sac larva (2 DAH), mouth-open larva (3 DAH), post yolk- sac larva (5 DAH), flexion larva (with complete pectoral fin, $15 \mathrm{DAH}$ ) and juvenile (metamorphosis completed, $25 \mathrm{DAH})$. Ten salinities were selected for testing the salinity tolerance of $I$. japonicus for the five larval stages, including $5,10,15,20,25,30,35,40,45$ and 50\%o, and five salinities (15-35\%) were set for juvenile. Seawater with different salinities was made by adding red sea salt (Red Sea) into freshwater. Salinity was determined using a handheld refractometer and a multiparameter water quality meter (YSI Professional Plus). At each specific developmental stage, 900 larvae (450 juveniles) were sampled from the rearing tanks, and allocated into thirty plastic containers containing $950 \mathrm{ml}$ water with ten salinities (three containers for each salinity). The larvae were kept in static water without feeding, and other environmental conditions were the same to the above mentioned. Dead larvae were counted and removed with 300 $\mathrm{ml}$ of seawater by glass pipette, and $300 \mathrm{ml}$ of fresh seawater was added once daily. Cessation of opercular movements and failure to respond to gentle prodding were the criteria used for death. This procedure was repeated until all fish died. The indexes for salinity tolerance used for the studies were survival activity index (SAI) and mean survival time (MST). SAI is expressed as a function of tolerance to starvation of larvae, positively correlated to the survival of larvae, and therefore defined as an index for larval quality of scorpionfish species (Matsuo et al. 2006). Mean survival time (MST) is defined as the mean survival time for all individuals in an experimental group over a 10-day period following direct transfer from salinity of pre-exposure to different salinities in this study (Watanabe et al. 1985). From the number of surviving larvae and survival duration (days), the SAI was calculated from the following equation:

$$
\mathbf{S A I}=\sum_{i=1}^{\cdot k} \cdot(\cdot(\cdot \boldsymbol{N}-\boldsymbol{h i} \cdot) \cdot \boldsymbol{i} \cdot / \cdot \boldsymbol{N})
$$

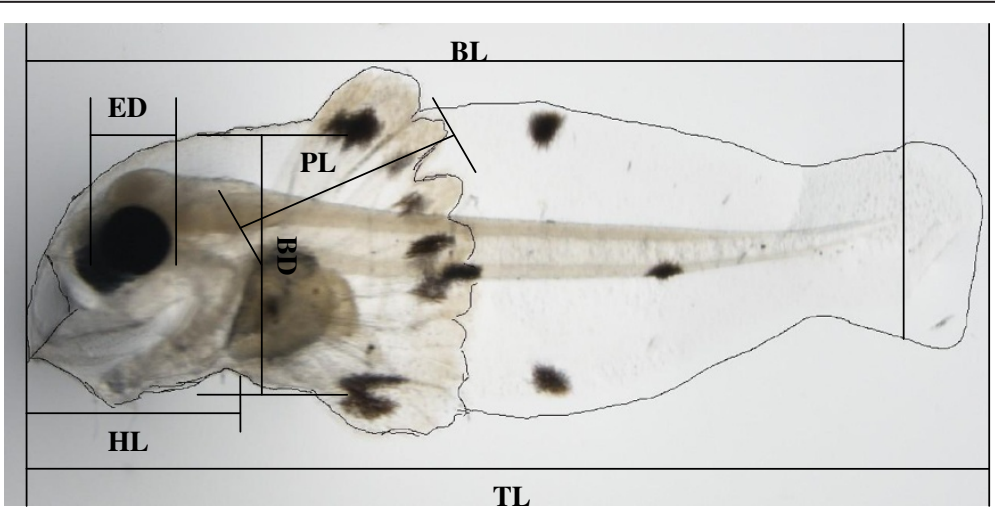

Figure 1 Morphometric characters measured in the devil stinger Inimicus japonicus larvae, body depth (BD), eye diameter (ED), head length $(\mathrm{HL})$, pectoral fin length $(\mathrm{PL})$, body length $(\mathrm{BL})$ and total length $(\mathrm{TL})$. 
where $N$ is the total number of supplied larvae, $h i$ is the cumulative mortality by the day $i$, and $k$ is the number of days elapsed until all larvae died due to starvation. The average SAI was calculated for each batch and was used for further analysis.

\section{Statistical analysis}

Data on salinity tolerance at six stages were statistically analysed using one-way analysis of variance (ANOVA), differences were considered significant at $P<0.05$, and Student-Newman-Keuls post hoc multiple range tests
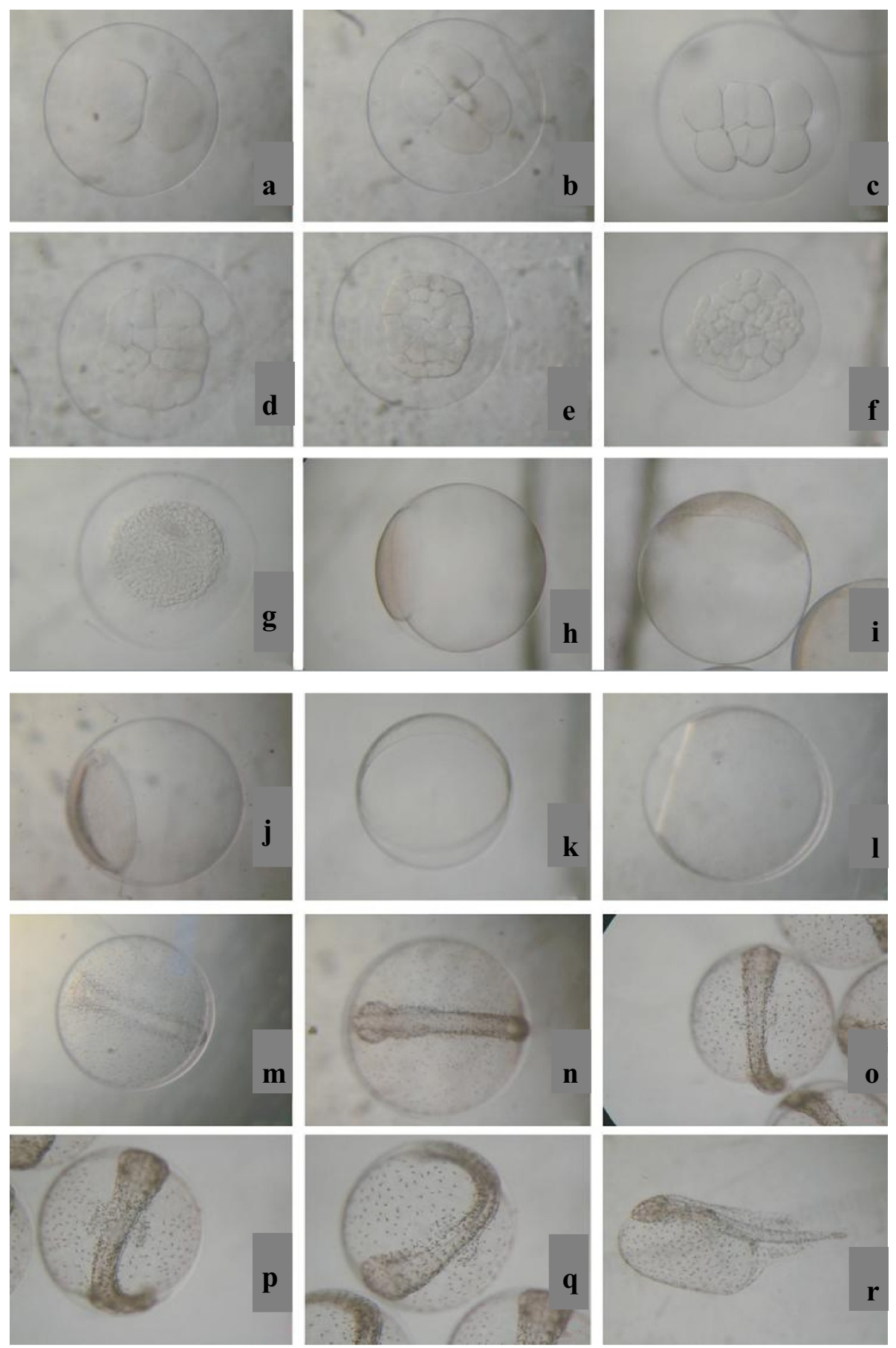

Figure 2 Embryonic development of Inimicus japonicas, a:2-cell stage; b: 4-cell stage; c: 8-cell stage; d: 16-cell stage; e: 32-cell stage; f: 64-cell stage; g: Morula stage; h: Early blastula stage; i: Late blastula stage; j: Early gastrula stage; k: Mid gastrula stage; l: Late gastrula stage; m: Embryoid body formation; $\mathrm{n}$ : Formation of optic vesicle; o: Appearance of myomere; p: Efficiency stage of muscles; q: Pre-hatching stage; r: Newly hatched larva. 
were carried out to determine which treatments were different. Prior to the analysis, normality of the data was evaluated by using the Shapiro-Wilk's W test and homogeneity of variances was checked by Levene's test using the statistical software SPSS 17.0. The results are expressed as the means \pm S.D. of the data.

\section{Results}

\section{Embryonic development}

The egg was buoyant, transparent and spherical in shape, lacking oil droplet. The mean diameter of the egg was $1.40 \pm 0.05 \mathrm{~mm}$. The cleavage of eggs was meroblastic and the first cleavage (two-celled stage) occurred within 0:23 hours after spawning (Figure 2a). Blastodisc divided to form two equal cells. The second cleavage occurred 0:32 hours and four blastomeres were clearly observed (Figure 2b). Blastodisc divided via meridional cleavage to form four equal cells. Then the eggs cleaved into 8 and 16 cells respectively. The third cleavage was horizontal and resulted in a $2 \times 4$ array (Figure $2 \mathrm{c}$ ). The forth cleavage occurred in two separate planes, cleavage furrow parallel to second cleavage plane and resulted in a $4 \times 4$ array (Figure 2d). Eight and 16 cell stages were observed at 0:40 hours and 1:02 hours respectively (Figure 2c and $\mathrm{d}$ ). The fifth cleavage took place after 1:35 hours from spawning (Figure 2e). Blastoderm divided via meridional cleavage into 32 cells and the 32 blastomeres were formed. After the sixth cleavage with 64 cells at 2:05 hours, the cells became smaller and were arranged irregularly (Figure 2f). At 4:05 hours, all blastomeres congregated like a mulberry, the animal pole uplifted like a hillock, and cell sizes varied differently (Figure 2g). The early blastula stage occurred at the vegetal pole 6:30 hours after spawning (Figure 2h). At this stage, the crowded cells expanded over the yolk and the blastomeres were divided asynchronously. The late blastula stage consisted of a multicellular blastomere (Figure 2i) and fully completed at approximately 9:40 hours. The gastrulation started at 11:36 hours after spawning (Figure 2j). Blastoderm cells spread over the yolk and epibolic cells increased at this stage. The embryo reached $50 \%$ epiboly at 13:45 hours after spawning and the blastoderm covered $50 \%$ of the yolk (Figure $2 \mathrm{k}$ ). $75 \%$ epiboly stage was completed at 15:00 (Figure 2l). Neurula appeared at 19:47 hours, the prototype of the neural plate formed, head part uplifted, yolk plug exposed, pigments on the embryonic shield and yolk sac can be seen (Figure $2 \mathrm{~m}$ ). Pharyngula stage began at 22:23 hours, and a pair of kidney-shaped optic vesicles on both sides of the head was observed at this point (Figure 2n). At 25:46 hours, the embryoid surrounded the yolk sac, in the center of the embryoid, 8-11 myomeres formed (Figure 2o). The formation of the otic capsule started at 38:35 hours and embryo began to spin at this time (Figure 2p). The eye development and heart beat took place and body movement in the capsule was observed at 42:45 hours (Figure 2q). Larvae were hatched out at 44:05 hours, firstly, the head came out of the capsule, and then the tail swung hard to get off the capsule (Figure 2r). Hatching rates were $85-90 \%$ in aquarium at $50 \mathrm{~h}$ after spawning. The complete embryonic development was summarized in Table 1.

\section{Larval development and morphological observations}

Newly hatched larvae (TL: $4.03 \pm 0.15 \mathrm{~mm}$ ) in the posthatching stage were laterally compressed and initially elongated. The head was closed to the yolk sac and the yolk sac was more than $50 \%$ of the total length, and the eyes were still unpigmented (Figure 2r). The body was transparent but pigmentation e.g., melanin and yellow pigments have appeared in the whole body (Figure $2 \mathrm{r}$ ). 1DAH (TL: $4.23 \pm 0.19 \mathrm{~mm}$, Figure 3a), the yolk sac was reduced like a ball. The mouth and anus were closed and the undifferentiated alimentary tract appeared as a short tube. Eyes were not pigmented and three big spots of melanophores were scattered on the edge of body. The primordial pectoral fin fold was well developed in the sagittal plane but no fins were differentiated. A bigger round black spot were observed on the base of pectoral fin. $2 \mathrm{DAH}$ (TL: $4.38 \pm 0.11 \mathrm{~mm}$, Figure $3 \mathrm{~b}$ ), the yolk sac became smaller, pigmentation increased over the eyes and the body but they were still translucent. Black melanophores were scattered on the head region, ventral and dorsal side of the body. The digestive track was a little inflated and dark. The primordial fin was slightly differentiated, no anal and dorsal fins were differentiated but pectoral fin bud was present. The larvae could not swim actively but short periods of swimming were observed. $3 \mathrm{DAH}$ (TL: $4.54 \pm 0.16 \mathrm{~mm}$, Figure 3c), the eyes were pigmented, the mouth and anus opened, and the larvae started to feed exogenously. The pectoral fin was obvious with some big pigment spots. Swimming activity increased and the pectoral fin spread like a fan to maintain balance. $5 \mathrm{DAH}$ (TL: $4.89 \pm 0.21 \mathrm{~mm}$, Figure $3 \mathrm{~d}$ ), the yolk sac has been completely absorbed and the larvae started to swim actively. The pectoral fin increased beyond the body depth. The eyes became very prominent and were fully pigmented. The larvae displayed phototaxis. There was a big black spot at the end of each ray of the spokewise pectoral fin. Pigmentation increased on the head and lateral parts of the body, black pigments were dominant, but yellow pigments were also present. The larvae swam very well. $8 \mathrm{DAH}$ (TL: $5.17 \pm 0.23 \mathrm{~mm}$, Figure $3 \mathrm{e}$ ), the pectoral fin increased, and the edge was wavy, yellow pigments were dense at the edge of the fins. The digestive tract was full of food. At this point, the larvae were pelagic and swam using the pectoral fin. $10 \mathrm{DAH}$ (TL: $5.48 \pm 0.32 \mathrm{~mm}$, 
Table 1 Embryonic development stages of Inimicus japonicus at $21^{\circ} \mathrm{C}$

\begin{tabular}{|c|c|c|c|c|}
\hline Main stages & Substages & Time (h:min) & Description & Figure \\
\hline \multirow[t]{7}{*}{ Zygote } & 2-cell stage & $0: 23$ & $\begin{array}{l}\text { First cleavage, blastodisc divided via meridional } \\
\text { cleavage to form two equal cells }\end{array}$ & $1 \mathrm{a}$ \\
\hline & 4-cell stage & $0: 32$ & $\begin{array}{l}\text { Second cleavage, dividing the blastodisc into } 4 \\
\text { blastomeres }\end{array}$ & $1 b$ \\
\hline & 8-cell stage & $0: 40$ & Third cleavage, $2 \times 4$ array of blastomeres & $1 \mathrm{c}$ \\
\hline & 16-cell stage & $1: 02$ & Fourth cleavage, 16 blastomeres can be seen & $1 d$ \\
\hline & 32-cell stage & 1:35 & $\begin{array}{l}\text { Fifth cleavage, } 2 \text { regular tiers (horizontal rows) of } \\
\text { blastomeres, sometimes in } 4 \times 8 \text { array }\end{array}$ & $1 e$ \\
\hline & 64-cell stage & 2:05 & Sixth cleavage, 64 blastomeres were ranked irregularly & if \\
\hline & Morula stage & 4:05 & $\begin{array}{l}\text { The blastomeres were still distinct but the number of } \\
\text { blastomeres can not be counted }\end{array}$ & $1 \mathrm{~g}$ \\
\hline \multirow[t]{2}{*}{ Blastula } & Early blastula stage & $6: 30$ & $\begin{array}{l}\text { The blastomeres were no longer distinguishable, the } \\
\text { blastocoel began to form, and endoderm germ layer } \\
\text { appeared }\end{array}$ & $1 \mathrm{~h}$ \\
\hline & Late blastula stage & $9: 40$ & $\begin{array}{l}\text { Epibolic cells increased, the archenteron can be seen, } \\
\text { endoderm germ layer invaginated and the ectoderm } \\
\text { layer formed }\end{array}$ & $1 \mathrm{i}$ \\
\hline \multirow[t]{3}{*}{ Gastrula } & Early gastrula stage & 11:36 & $\begin{array}{l}\text { Blastoderm cells begin to spread over the yolk, and } \\
\text { blastoderm remains uniform in thickness }\end{array}$ & $1 \mathrm{j}$ \\
\hline & Mid gastrula stage & 13:45 & $\begin{array}{l}\text { Germ ring epiboled } 1 / 2 \text { of yolk sac, embryonic shield } \\
\text { visible from animal pole }\end{array}$ & $1 \mathrm{k}$ \\
\hline & Late gastrula stage & 15:00 & $\begin{array}{l}75 \% \text { coverage of the yolk cell by the blastoderm, dorsal } \\
\text { side distinctly thicker; epiblast, hypoblast, evacuation } \\
\text { zone visible }\end{array}$ & 11 \\
\hline Neurula & embryoid body formation & 19:47 & $\begin{array}{l}\text { The prototype of the neural plate appeared, head part } \\
\text { uplifted, yolk plug exposed, pigments on the embryonic } \\
\text { shield and yolk sac can be seen }\end{array}$ & $1 \mathrm{~m}$ \\
\hline \multirow[t]{4}{*}{ Pharyngula } & Formation of optic vesicle & $22: 23$ & $\begin{array}{l}\text { On both sides of the head, a pair of kidney-shaped } \\
\text { protrusions can be seen }\end{array}$ & $1 \mathrm{n}$ \\
\hline & Appearance of myomere & 25:46 & $\begin{array}{l}\text { Embryoid surrounded the yolk sac, in the center of the } \\
\text { embryoid, 8-11 myomeres can be seen. }\end{array}$ & 10 \\
\hline & Muscular effect & $38: 35$ & Embryo begins to spin frequently, heart beat $70-75 / \mathrm{min}$ & $1 p$ \\
\hline & Pre-hatching stage & $42: 45$ & The embryo shows conspicuous muscular contractions & $1 q$ \\
\hline Hatching & newly hatched larva & 44:05 & General transparent, floating on the water surface & $1 \mathrm{r}$ \\
\hline
\end{tabular}

Figure 3f), pectoral fins were well developed with 9 rays, dorsal and anal fins began early differentiation. The caudal-fin rays formed. The notochord end was slightly flexed. There were clusters of pigment over the body. The larvae swam very well. 13 DAH (TL: $5.85 \pm 0.29$ $\mathrm{mm}$, Figure $3 \mathrm{~g}$ ), the number of caudal-fin rays increased, but the dorsal and anal fins showed no difference compared with $10 \mathrm{DAH}$ larvae. There were clusters of yellow pigment on the pectoral fin base. 15 DAH (TL: $5.92 \pm$ $0.33 \mathrm{~mm}$, Figure $3 \mathrm{~h}$ ), anal and dorsal fins began to develop and caudal fin rays were developed. The stomach of larvae contained food, ventral region of larvae was swollen and orange. Spinous protuberances were present on the head and opercular. $20 \mathrm{DAH}$ (TL: $10.76 \pm 0.63$ $\mathrm{mm}$, Figure $3 \mathrm{i}$ ), the body color was pale yellow, and dorsal, caudal and anal fins differentiated well. The black spots on the dorsal and anal fins disappeared. A gold yellow zone on the pectoral fin was observed. The fish changed swimming to settling on the bottom of the tank. 25 DAH (TL: $12.06 \pm 0.54 \mathrm{~mm}$, Figure 3j), morphological metamorphosis was completed and the larvae completely transformed into juveniles. 30 DAH (TL: $15.65 \pm 0.93 \mathrm{~mm}$, Figure $3 \mathrm{k}$ ), the morphology of the fish was similar to the $25 \mathrm{DAH}$ fish, but the pigmentation increased significantly. The body shape and pigmentation pattern were similar to the adult fish. Yellow and black stripes were present on the body and fins. 40 DAH (TL: $19.10 \pm 1.22 \mathrm{~mm}$, Figure 3l), the body was almost completely covered with pigment. All fins developed well. The color of the body was tawny, red and yellow spots spread on the fins.

Growth of the black skirt tetra larvae followed an exponential curve during the larval stages and is represented by the equation $y=3.8984 \mathrm{e}^{0.0389 \mathrm{x}}\left(\mathrm{R}^{2}=0.9404\right.$, $\mathrm{n}=270$ where $\mathrm{y}$ is total length (TL) $\mathrm{mm}$ and $\mathrm{x}$ is DAH (Figure 4). Six larval development stages were observed 

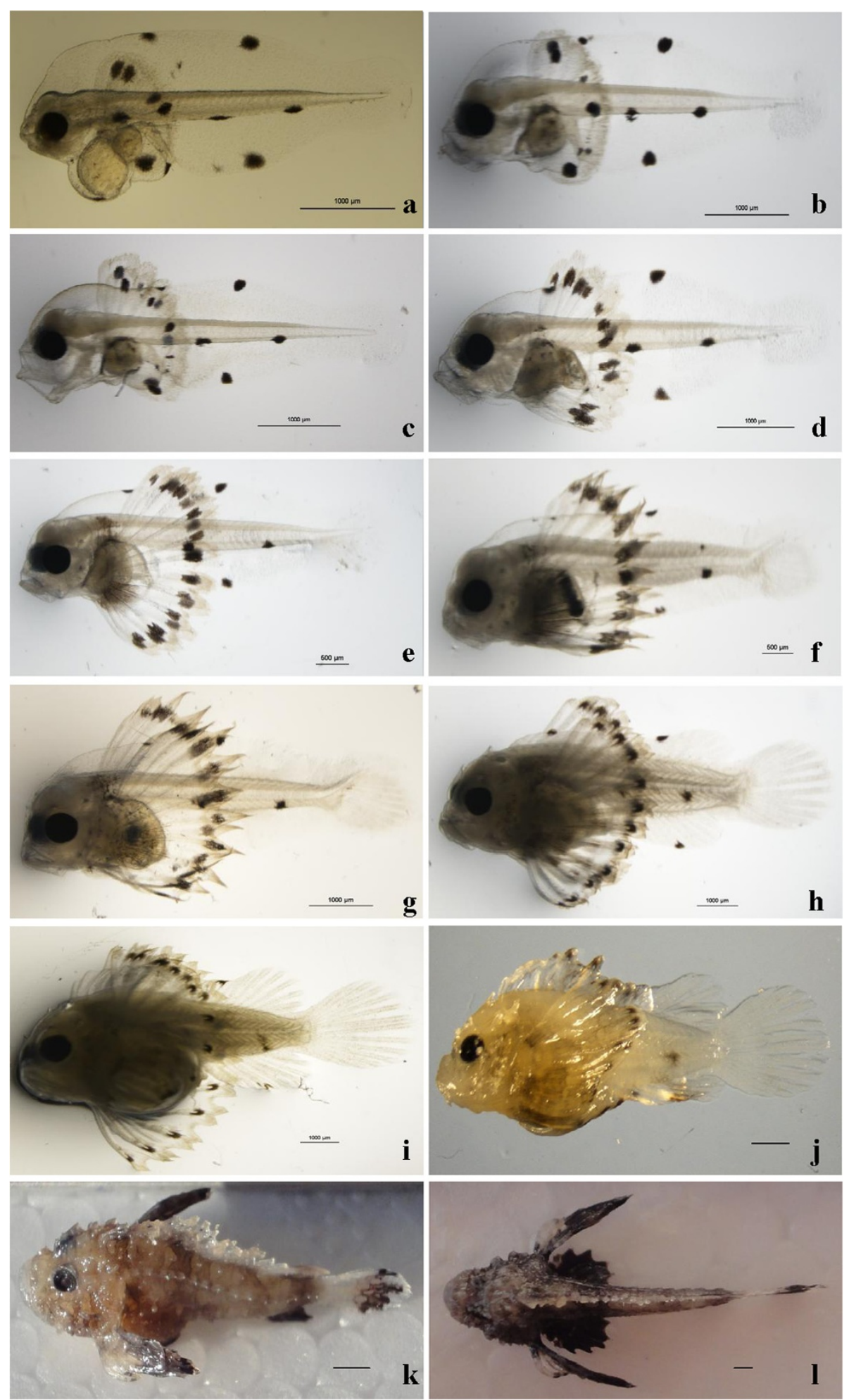

Figure 3 Larval development of Inimicus japonicas, a: Post-hatching stage, 1 DAH; b: yolk-sac stage, 2 DAH; c: Larvae with mouth opened, 3 DAH; d: Post yolk-sac stage, 5 DAH; e: Preflexion larva, exogenous feeding, 8 DAH; f: Preflexion larva, 10 DAH; g: Flexion stage, notochord flexion started, $13 \mathrm{DAH}$; h: Postflexion larva, swim bladder with two chambers was visible $15 \mathrm{DAH}$; i: Postflexion larva, $20 \mathrm{DAH}$; j: End of metamorphosis, $25 \mathrm{DAH}$; : Juvenile of $30 \mathrm{DAH}$; l: Juvenile of $40 \mathrm{DAH}$. Scale bars $=1 \mathrm{~mm}$. 


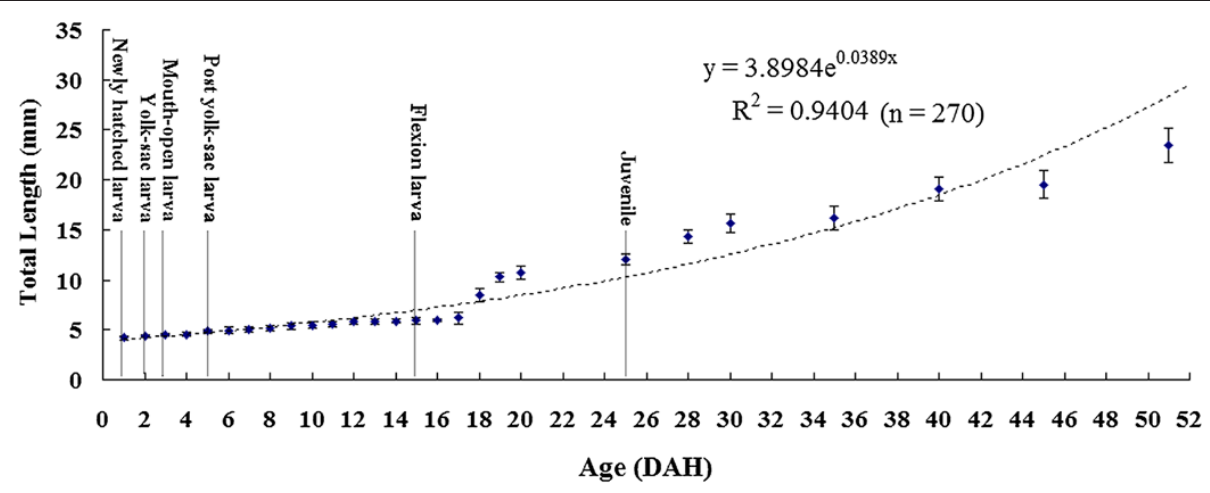

Figure 4 Growth of Inimicus japonicas larvae from hatch to $51 \mathrm{DAH}$. Each point represents the mean total length \pm SD.

after hatching; newly hatched larva, yolk-sac larva, mouth-open larva, post yolk-sac larva, flexion larva, and juvenile. The yolk sac has been completely consumed at $5 \mathrm{DAH}$. Notochord has been flexed between $13 \mathrm{DAH}$ and $15 \mathrm{DAH}$. All the meristic characters were completely developed and juvenile stage started at $25 \mathrm{DAH}$.

\section{Salinity tolerance of larvae at different developmental stages}

One-way ANOVA results on the effects of salinities on SAI in different developmental stages were summarized in Table 2. For the newly hatched larvae, the value of SAI was zero at salinity 5 and high values with no significant difference were present among salinity $10-30 \%$, and then decreased with salinity (Figure 5a). For the yolk-sac larvae, the highest SAI was observed at salinity $15 \%$, then the SAI decreased with salinity increase, and SAI values under salinity $15-20 \%$ were significantly

Table 2 Summary of one-way ANOVA results on the effect of salinity on Survival activity index (SAI) and Mean Survival Time (MST) of Inimicus japonicus at early stage

\begin{tabular}{llllll}
\hline Parameter & Stage & df & MS & F & P-value \\
\hline SAI & Newly hatched larva & 9 & 199.589 & 29.744 & $<0.001$ \\
& Yolk-sac larva & 9 & 194.737 & 18.001 & $<0.001$ \\
& Mouth-open larva & 9 & 363.965 & 47.469 & $<0.001$ \\
Post yolk-sac larva & 9 & 249.507 & 130.224 & $<0.001$ \\
Flexion larva & 9 & 122.846 & 34.973 & $<0.001$ \\
Juvenile & 4 & 1.128 & 6.876 & 0.006 \\
MST & Newly hatched larva & 9 & 13.498 & 277.921 & $<0.001$ \\
& Yolk-sac larva & 9 & 13.003 & 63.454 & $<0.001$ \\
& Mouth-open larva & 9 & 21.216 & 69.987 & $<0.001$ \\
& Post yolk-sac larva & 9 & 16.872 & 280.507 & $<0.001$ \\
Flexion larva & 9 & 6.357 & 30.312 & $<0.001$ \\
& Juvenile & 4 & 0.627 & 6.56 & 0.007 \\
\hline
\end{tabular}

Figure legends. higher than that at other salinities (Figure 5b). The similar trends were also observed for mouth-open larva and post yolk-sac larvae (Figure $5 c$ \& d), with both higher SAI values under medium salinities. However, the flexion larvae showed a wide salinity tolerance with a higher SAI value under salinity 5-20\%o (Figure 5e). For the juvenile, the highest SAI was observed at salinity $20 \%$ among five salinities, but showed no significant difference between salinity 15\% to 20\% (Figure 5f).

The MSTs of different developmental stages under various salinities were showed in Figure 6, and one-way ANOVA results were summarized in Table 2. For the newly hatched larvae, the MST under salinity $20 \%$ and $25 \%$ was significantly higher than that at other salinities, and was lowest at salinity 5\% (Figure 6a). For the yolksac larvae, the lowest MST was under salinity $5 \%$, the highest MST was at salinity 15\%, and then decreased with salinity increase (Figure 6b). Similar trends were also found in mouth open and post-yolk sac larvae, both highest MST values were present at medium salinities (Figure $6 c$ \& d). However, flexion larvae showed high MST under salinity 5\% to 20\% (Figure 6e). In juvenile, the MST showed no significant difference among salinity 15-30, but lower at salinity 35\% (Figure 6f).

\section{Discussion}

Scorpaeniformes fish has two reproductive types, one is ovoviviparous, such as false kelpfish Sebastiscus marmoratus; and the other is fertilized externally, like $I$. japonicus. There are three types of teleost eggs, buoyant, sticky and demersal, and most marine teleostean spawn buoyant eggs. Usually one oil globule is contained in the egg, playing a role of floating. However, oil globule could not be found in I. japonicus, but the eggs were still floating in the seawater with a salinity of $30 \%$, indicating ups and downs of eggs of I. japonicus is related to the water content in the eggs. In this study, the full developmental sequence of the devil stinger I. japonicus from egg to juvenile in controlled aquarium conditions was stated. 

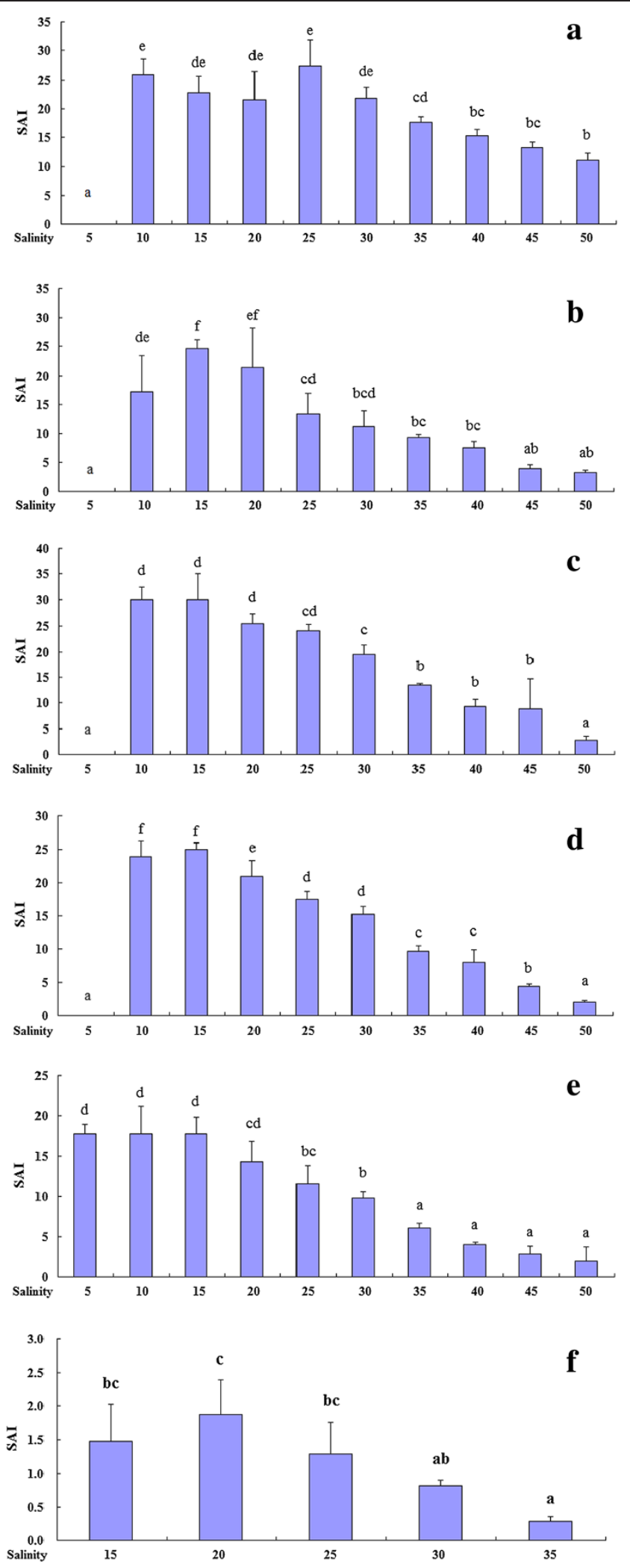

Figure 5 Survival activity index under different salinities at different developmental stages in the Inimicus japonicas, a: newly hatched larva (1 DAH), b: yolk-sac larva (2 DAH), c: mouth-open larva (3 DAH), d: post yolk-sac larva (5 DAH), e: flexion larva (15 DAH) and f: juvenile (25 DAH). 

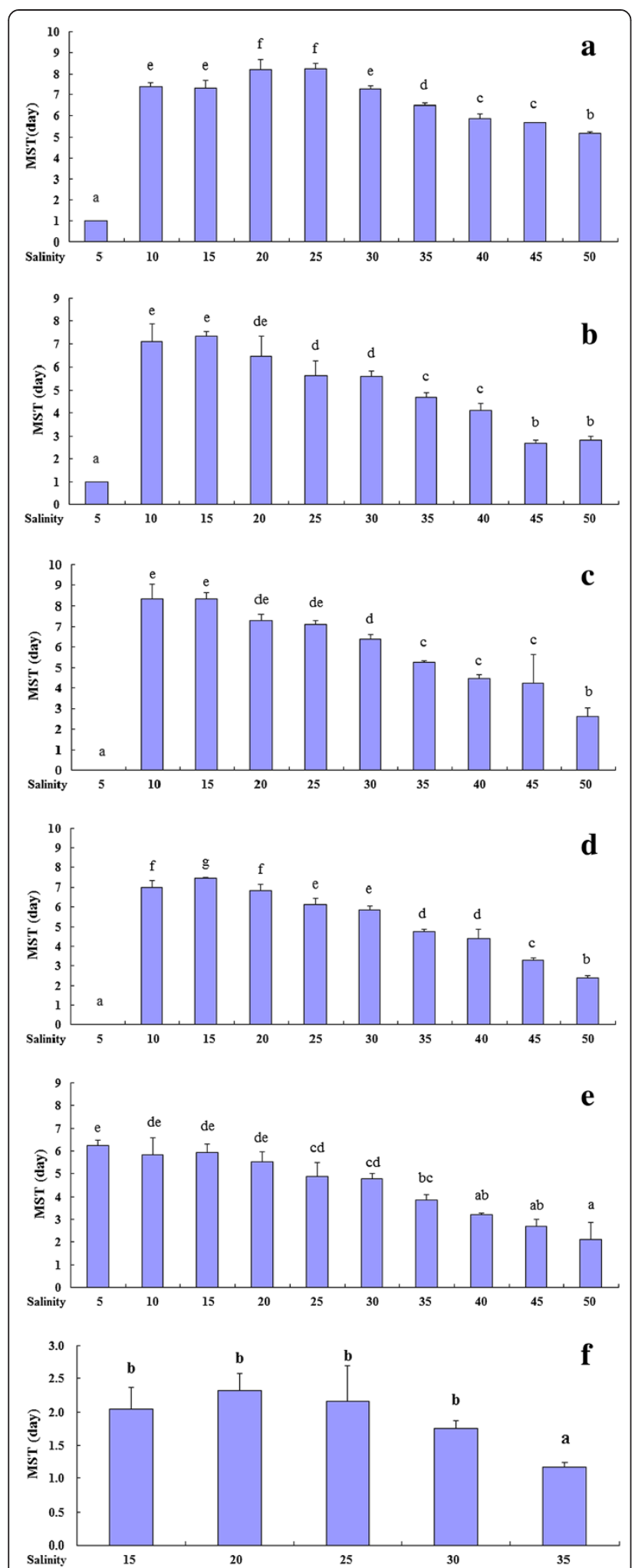

Figure 6 Mean survival time under different salinities at different developmental stages in the Inimicus japonicas, a: newly hatched larva (1 DAH), b: yolk-sac larva (2 DAH), c: mouth-open larva (3 DAH), d: post yolk-sac larva (5 DAH), e: flexion larva (15 DAH) and f: juvenile (25 DAH).
These results enabled us to compare the development and morphology of embryos of I. japonicus with those of other teleost fishes in detail. During the embryonic development of $I$. japonicus, the same events were observed as those seen in zebrafish Danio rerio (Kimmel et al. 1995), roughskin sculpin Trachidermus fasciatus (Takeshita et al. 1997; Wang et al. 2004), and cottid fish Hemilepidotus gilberti (Hayakawaa and Munehara 2001), and their stage definitions could be consistently adopted to describe the embryonic development of I. japonicus. Therefore, the embryonic development of $I$. japonicus can be considered to follow the general developmental pattern of teleosts. Egg size is an important consideration for egg and larval quality during incubation and rearing in aquaculture. The average diameter of most Scorpaeniformes fish eggs are around 1.2-2.0 mm, however, the size range is wide. Egg diameters of some Scorpaeniformes fish were reported as: $1.2-1.3 \mathrm{~mm}$ for I. japonicus (Kadomura et al. 2006; Kim et al. 2012), 1.3 $\mathrm{mm}$ for non-copulatory sculpin Hemilepidotus gilberti (Hayakawaa and Munehara 2001), 1.5-1.78 (1.98-2.21) $\mathrm{mm}$ for roughskin sculpin, Trachidermus fasciatus (Wang et al. 2004; Takeshita et al. 1997). The egg of devil stinger is spherical, floating and has approximately $1.40 \mathrm{~mm}$ average diameter, which is similar to its previous reports. The egg size and fecundity are determined by several factors, i.e., broodstock age, broodstock size, feed and water quality (Celik et al. 2012).

In most fish species the blastomeres are regular in size and shape (Hall 2008). In the devil stinger, first five cleavages divided the blastodisc into 32 equal-sized blastomeres at the animal pore and horizontal cleavage occurred between 64 and 128 cell stages (after the fifth division). In zebrafish Danio rerio (Kimmel et al. 1995), Atlantic cod Gadus morhua (Hall et al. 2004), and cichlid fish Cichlasoma dimerusn (Meijide and Guerrero 2000), the first horizontal cleavage occurs at the sixth cleavage, between the 32 and the 64 cell stages. It occurs between the 16 and 32 cell stages in the medaka Oryzias latipes (Iwamatsu 1994) and common snook Centropomus undecimalis (Yanes-Roca et al. 2012). It occurs even earlier in the Holostean fish Amia calva (between the 8 and the 16 cell stages) (Ballard 1986; Nakatsuji et al. 1997) and in the ice goby Leucopsarion petersii (between the 4 and the 8 cell stages) (Nakatsuji et al. 1997). Theoretical knowledge of embryonic development stages might be useful for incubation management with regard to environmental variables, thus larvae malformation and low productivity in captivity can be prevented (Celik et al. 2012). Furthermore, the information on embryonic and early larval development is important for large-scale seed production and aquaculture (Koumoundouros et al. 2001; Saillant et al. 2001). Teleost gastrulation was morphologically characterized by 
the presence of a germ ring (Arezo et al. 2005). In this study, gastrulation was observed at 11:36 hours and 50\% epiboly began 13:45 h. I. japonicus embryo reached the eight-somite stage at 25:46 hours and reached the prehatching stage at $42 \mathrm{~h}$ with muscular contractions.

The development of teleost fins during incubation process is various among different species. For example, the fins of Salmonidae fish begin to develop before hatching, but the fins of other fish, such as Nibea albiflora, Paralichthys olivaceus, Scomberomorus niphonius and Engraulis japonicus, start to develop after hatching, and the pectoral fin rays form late (Kendall et al. 1984). In I. japonicus, pectoral fin buds developed early at the late embryonic stage, showing a fan-shape film with black spot after hatching. The pectoral fin was larger than the head 3 days after hatching, and three melanin spots spread on the edge of the fin films. The larvae were inactive but short periods of swimming were observed. They started swimming freely within 3-4 days. While many marine fish larvae had two kinds of energy reserves, yolk and oil globule (Bjelland and Berit 2006), devil stinger has only yolk sac. The yolk sac is depleted within 3-4 days and the larvae start to feed exogenously before complete absorption of the yolk sac. Mouth opening was on the third day. Primordium of tail fin appeared at $6 \mathrm{DAH}$, at the moment the pectoral fin had developed very large, and ten nicks formed on the edge of the fin rays, with fuscous melanin in each ray. After 20 days, bright gold yellow stripes appeared on the large fanshape pectoral fin. In juveniles, the last two fin rays were separate from others. Possibly the development of pectoral fin in I. japonicus was corresponding with its functions. During larval stage, the fish were pelagic in the middleupper waters, and fan-shape pectoral fin played a role in balance. When ten nicks showed up in the pectoral fin, they made the swimming of the larvae more accurate and flexible, guaranteeing their feeding successful. In the postlarvae, they changed the free-swimming to nestling on the bottom, because the large pectoral fin made their swimming slow. However, the powerful pectoral fins make the fish move quickly for a short distance intermittently, facilitating its successful feeding. In the juvenile stage, fish transferred to benthonic life style completely, and swam slowly on the bottom of the water supporting by the two separate pectoral fin rays. The development of pectoral fins in $I$. japonicus is useful for enhancing the active search and predation efficiency of food organisms, which is similar to the pectoral fins of yellow croaker Larimichthys crocea and river loach Triplophysa bleekeri (Li and Yan 2009; Wang et al. 2010).

Early larval development of I. japonicus was divided into four main periods: Yolk-sac larva: the presence of a yolk sac ventrally in the body, between hatching and 4 DAH. Yolk sac was absorbed and larvae swam actively 3-4 days after hatching, and the onset of exogenous feeding occurred 3 days later. Post yolk-sac larva: this period began at absorption of yolk sac and ended at the start of upward flexion of the notochord (between 4 and $12 \mathrm{DAH}$ ). Flexion larva: this period (the period during notochord flexion) was characterized with the hypural bones assuming a vertical position, between 13 and 15 DAH. Postflexion larva: the period between completion of flexion and the juvenile stage, 16-25 DAH. Our findings may provide a basis for further studying the complete early life history of I. japonicus and commercial production of this fish. The results of this study can contribute to a better understanding of the embryonic and larval development of other commercial scorpionfish larvae. They can be used to explain some aspects of the early life history at culture conditions and to develop better larval culture methodologies in hatchery. Similarly, they will be helpful to increase success rates in the larval culture of some scorpionfish fish species.

In the present study, based on salinity tolerance rest, salinity tolerance of $I$. japonicus was comparative wide, ranging from $10-30 \%$, the optimum salinity range was $10-20 \%$. Reducing the salinity appropriately did not negatively affect the development and growth of the larvae, but increased the survival of the larvae. This result was similar to the other fish species, such as Nibea miichthioides (Huang et al. 1997) and Pagrosomus major (Wang 2002). The SAI and MST are popular indexes for evaluating the vitality and quality of the larvae during the marine fish larviculture. In the present study, their values were higher at the salinities of $10-20 \%$, and were lower when salinity was below $10 \%$ or above $25 \%$. During the observation, larval development was normal under such salinity levels, indicating SAI and MST could be regarded as useful indicators for evaluating the optimum salinity range. Lin (2008) reported that suitable salinity range for I. japonicus larvae was $19-31 \%$, but he did not test the difference of salinity tolerance among different developmental stages, which was observed in the present study. The suitable salinity range for newly hatched larvae was $10-30 \%$. However, the suitable salinities for the yolk-sac larvae, mouth open larvae, and post yolk-sac larvae were almost the same, ranging from 10\% to $20 \%$. The flexion larvae showed stronger low salinity tolerance compared with earlier stages, but this capacity decreased when the larvae finished metamorphosis. Except flexion larvae, all larvae were not able to survive at salinity $5 \%$, but lowering salinity appropriately could increase the survival of larvae in all developmental stages. Thus, in the present study, as a coastal fish species, the suitable salinity range for larviculture of $I$. japonicus was proved good at $10-20 \%$.

The SAI and MST displayed a similar trend under different salinities for all developmental stages. The SAI and MST are related to not only the nutrient storage, 
but also the living conditions. For example, when the salinity is suitable, the larvae only need to consume a little energy for osmoregulation, allocating large amount of energy to organ development and growth, thus survive longer under such conditions. However, when larvae are subject to lower or higher salinities, they need to spend more energy maintaining osmotic balance, and the other physiological functions are also affected, resulting in slow growth, reduced SAI and MST. In the present study, newly hatched larvae showed high SAI and MST at salinity $10-25 \%$, and larvae in other developmental stages showed higher values of the two parameters at salinity $10-20 \%$, indicating that the suitable salinity for the larviculture of $I$. japonicus should be reconsidered. Thus, the current salinity condition $(30 \%)$ in larviculture of Japanese devil stinger should be improved, and it is beneficial to reduce salinity moderately.

\section{Competing interests}

The authors declare that they have no competing interests.

\section{Authors' contributions}

YJ, GQ and WQ involved in designing and conducting experiment, YJ and LS involved in analyzing data and drafting the manuscript. All authors read and approved the final manuscript.

\section{Acknowledgments}

This work was supported in part by Science \& Technology Committee of Shanghai (11PJ1404500), National Natural Science Foundation of China (31072228), Shanghai Education Commission grant (10ZZ102), the Doctoral Program of Higher Education of China (20113104110002) and Shanghai Universities First-class Disciplines Project of Fisheries.

\section{Received: 1 April 2013 Accepted: 26 June 2013}

Published: 1 July 2013

\section{References}

Akatsu S, Al-Abdul-Elah KM, Teng SK (1983) Effects of salinity and water temperature on the survival and growth of brown-spotted grouper larvae (Epinephelus tauvina, Serranidae). J World Maricult Soc 14:624-635

Arezo MJ, Pereiro L, Berois N (2005) Early development in the annual fish Cynolebias viarius. J Fish Biol 66:1357-1370

Ballard WW (1986) Morphogenetic movements and a provisional fate map of development in the Holostean fish Amia cavla. J Exp Zool 238:355-372

Bjelland RM, Berit A (2006) Larval development in European hake (Merluccius merluccius L.) reared in a semi-intensive culture system. Aquacult Res 37:1117-1129

Boeuf G, Payan P (2001) How should salinity influence fish growth. Comp Biochem Physiol Part C 130:411-423

Celik I, Celik P, Cirik S, Gurkan M, Hayretdag S (2012) Embryonic and larval development of black skirt tetra (Gymnocorymbus ternetzi, Boulenger, 1895) under laboratory conditions. Aquacult Res 43:1260-1275

Chen H, Xie YQ, Lin GW, Lin XJ, Chen W, Wang XC (2009) Feeding rhythm and tolerance of starvation during early development stage of devil stinger, Inimicus japonicus. J Fishery Sci Chin 16:340-347

Faulk CK, Holt GJ (2006) Responses of cobia Rachycentron canadum larvae to abrupt or gradual changes in salinity. Aquaculture 254:275-283

Furuita H, Tanaka H, Yamamoto T, Shiraishi M, Takeuchi T (2000) Effects of n-3 HUFA levels in broodstock diet on the reproductive performance and egg and larval quality of the Japanese flounder, Paralichthys olivaceus. Aquaculture 187:387-398

Hall TE (2008) Pattern formation. In: Finn RN, Kapoor BG (eds) Fish larval physiology. Science Publishers, Enfield, New Hampshire, USA, pp 3-25

Hall TE, Smith P, Johnston IA (2004) Stages of embryonic development in the Atlantic cod Gadus morhua. J Morphol 259:255-270
Hayakawaa Y, Munehara H (2001) Facultatively internal fertilization and anomalous embryonic development of a non-copulatory sculpin Hemilepidotus gilberti Jordan and Starks (Scorpaeniformes: Cottidae). J Exp Mar Biol Ecol 256:51-58

Henne JP, Watanabe WO (2003) Effects of light intensity and salinity on growth, survival, and whole-body osmolality of larval southern flounder Paralichthys lethostigma. J World Aquacul Soc 34:450-465

Huang YC, Zheng JH, Zhou ZB (1997) Effects of salinity on embryonic development and larval survival in Nibea miichthioides. J Fujian Fish 1:34-37

Imamura H, Yabe M (1997) Osteological development of the lumpfish, Inimicus japonicus (Pisces: Synanceiidae). Ichthyol Res 45:53-67

Iwamatsu T (1994) Stages of normal development in the medaka Oryzias latipes. Zool Sci 11:825-839

Jones PW, Martin FD, Hardy JD Jr (1978) Development of fishes of the midAtlantic Bight: an atlas of egg, larval, and juvenile stages, vol I: Acipenseridae through Ictaluridae. U.S. Fish and Wildlife Service, Office of Biological Programs. FSW/OBS-78/12. Ft. Collins, CO

Kadomura K, Nakashima T, Kurachi M, Yamaguchi K, Oda T (2006) Production of reactive oxygen species (ROS) by devil stinger (Inimicus japonicus) during embryogenesis. Fish Shellfish Immunol 21:209-214

Kendall AW, Ahlstrom EH, Moser HG (1984) Early life history stages of fishes and their characters. In: Moser HG, Richards WJ, Cohen DM, Fahay MP, Kendall AW, Richardson SL (eds) Ontogeny and systematics of fishes: American Society of Ichthyologists and Herpetologists, Special Publication No. 1. Allen Press Inc, Lawrence, Kansas, USA, pp 11-22

Kim D, Naruse S, Kadomura K, Nakashima T, Jiang Z, Yamasaki Y, Yamaguchi K, Oda T (2012) Transitional reactive oxygen species (ROS) production in fertilized egg embryos of devil stinger (Inimicus japonicus), a marine fish species. Biosci Biotechnol Biochem 76:1561-1564

Kimmel CB, Ballard WW, Kimmel SR, Ullman B, Schilling TF (1995) Stages of embryonic development of the zebrafish. Dev Dynam 203:253-310

Koumoundouros G, Divanach P, Kentouri M (2001) Osteological development of Dentex dentex (Osteichthyes: Sparidae): dorsal, anal, paired fins and squamation. Mar Biol 138:399-406

Li ZL, Yan TM (2009) Morphological development of Triplophysa bleekeri (Sauvage \& Dabry de Thiersant, 1874) embryo and larvae. Acta Hydrobiol Sin 33:636-642

Lin XJ (2008) Effects of salinity on the embryonic development and larval growth of Inimicus japonicus. J Fujian Fish 12:24-26

Liu ZY, Quan HF (2005) Research on the technique for artificial breeding of Inimicus japonicus. J Shanghai Fish Univ 14:30-34

Martinez GM, Bolker JA (2003) Embryonic and staging of summer flounder (Paralichthys dentatus). J Morphol 255:162-176

Matsuo Y, Kasahara Y, Hagiwara A, Sakakura Y, Arakawa T (2006) Evaluation of larval quality of viviparous scorpionfish Sebastiscus marmoratus. Fisheries Sci 72:948-954

Meijide FJ, Guerrero GA (2000) Embryonic and larval development of a substratebrooding cichlid Cichlasoma dimerus (Heckel, 1840) under laboratory conditions. J Zool 252:481-493

Moustakas CT, Watanabe WO, Copeland KA (2004) Combined effects of photoperiod and salinity on growth, survival, and osmoregulatory ability of larval southern flounder Paralichthys lethostigma. Aquaculture 229:159-179

Nakatsuji T, Kitano T, Akiyama N, Nakatsuji N (1997) Ice goby (Shiro-uo), Leucopsarion petersii, may be a useful material for studying teleostean embryogenesis. Zool Sci 14:443-448

Nozaki R, Takushima M, Mizuno K, Kadomura K, Yasumoto S, Soyano K (2003) Reproductive cycle of devil stinger, Inimicus japonicas. Fish Physiol Biochem 28:217-218

Ruttanapornvareesakul Y, Sakakura Y, Hagiwara A (2007) Effect of tank proportions on survival of seven-band grouper Epinephelus septemfasciatus (Thunberg) and devil stinger Inimicus japonicus (Cuvier) larvae. Aquacult Res 38:193-200

Saillant E, Chatain B, Fostier A, Przybyla C, Fauvel C (2001) Parental influence on early development in the European sea bass. J Fish Biol 58:1585-1600

Sampaio LA, Freitas LS, Okamoto MH, Louzada LR, Rodrigues RV, Robaldo RB (2007) Effects of salinity on Brazilian flounder Paralichthys orbignyanus from fertilization to juvenile settlement. Aquaculture 262:340-346

Santerre MT (1976) Effects of temperature and salinity on the eggs and early larvae of Caranx mate (Pisces: Carangidae) in Hawaii. J Exp Mar Biol Ecol 21:51-68

Swanson C (1996) Early development of milkfish: effects of salinity on embryonic and larval metabolism, yolk absorption and growth. J Fish Biol 48:405-421 
Takeshita N, Onikura N, Matsui S, Kimura S (1997) Embryonic, larval and juvenile development of the roughskin sculpin, Trachidermus jasciatus (Scorpaeniformes: Cottidae). Ichthyol Res 44:257-266

Takushima M, Nozaki R, Kadomura K, Yasumoto S, Soyano K (2003) Induced ovulation using LHRHa and artificial fertilization in devil stinger, Inimicus japonicas. Fish Physiol Biochem 28:521-522

Tandler A, Anav FA, Choshniak I (1995) The effect of salinity on growth rate, survival and swimbladder inflation in gilthead seabream, Sparus aurata, larvae. Aquaculture 135:343-353

Wang HS (2002) Effects of salinity on egg development and growth, larval and juvenile survival rate of Pagrosomus major. J Fish Sci China 9:33-37

Wang JQ, Pan LD, Liang TH, Gan HC (2004) Preliminary study on embryonic development of the roughskin sculpin, Trachidermus fasciatus (Scorpaeniformes: Cottidae). J Fudan Univ (Nat Sci) 43:250-256

Wang QR, Ni YY, Lin LM, Wang ZY (2010) Development of the vertebral column and the pectoral and caudal fins in larvae of the larvae yellow croaker Larimichthys crocea (Richardson). Acta Hydrobiol Sin 34:467-472

WatanabeWO KCM, Huang MC (1985) The ontogeny of salinity tolerance in the tilapias Oreochromis aureus, 0 . niloticus, and an 0 . mossambicus $\times 0$. niloticus hybrid, spawned and reared in freshwater. Aquaculture 47:353-367

Yanes-Roca C, Rhody NR, Nystrom M, Wittenrich ML, Main KL (2012) Embryonic and early larval development in hatchery-reared common snook. N Am J Aquacult 74:499-511

doi:10.1186/2193-1801-2-289

Cite this article as: Wang et al:: Ontogenesis from embryo to juvenile and salinity tolerance of Japanese devil stinger Inimicus japonicus during early life stage. SpringerPlus :

\section{Submit your manuscript to a SpringerOpen ${ }^{\circ}$ journal and benefit from:}

- Convenient online submission

- Rigorous peer review

- Immediate publication on acceptance

- Open access: articles freely available online

- High visibility within the field

- Retaining the copyright to your article

Submit your next manuscript at $>$ springeropen.com 